\title{
Effect of Imidacloprid on Incidence of Tomato yellow leaf curl virus
}

\author{
N. E. Ahmed, Arid Land Research Center, Tottori University, Hamasaka, 1390, Tottori 680-0001, Japan; H. O. \\ Kanan, Crop Protection Center, Agricultural Research Corporation, Wad Medani, Sudan; Y. Sugimoto, Y. Q. Ma, \\ and S. Inanaga, Arid Land Research Center, Tottori University, Hamasaka 1390, Tottori 680-0001
}

\begin{abstract}
Ahmed, N. E., Kanan, H. O., Sugimoto, Y., Ma, Y. Q., and Inanaga, S. 2001. Effect of imidacloprid on incidence of Tomato yellow leaf curl virus. Plant Dis. 85:84-87.

Confidor, an imidacloprid insecticide, was used in two applications at four rates (47.6, 71.4, 95.2, and $119 \mathrm{~g}$ a.i./ha) for indirectly controlling Tomato yellow leaf curl virus (TYLCV) in field plantings of tomato. This spray regimen was compared with standard applications of cypermethrins at 10- to 15-day intervals throughout the growing season. In three field trials, a combination of integrated pest management (IPM) practices and two applications of Confidor at the two highest rates immediately after planting and 6 weeks later, protected tomato plants against the disease until 12 weeks after sowing. All rates of Confidor reduced disease incidence compared with standard chemical control applied in an integrated strategy, and quantitative efficacy increased with increase of insecticide rate. In the three seasons, the mean incidence of TYLCV 12 weeks after sowing was $42.7 \%$ in plots not adopting IPM compared with $15.7 \%$ in those that did. Disease incidence was reduced by Confidor treatments to 2.2 to $17 \%$. Confidor-treated plots consistently had higher yields than control plots, and the yields decreased with the decrease in the rate of Confidor application. Confidor offers several advantages over standard applications of cypermethrins to control TYLCV. When applied immediately after planting, its long-lasting systemic activity protected the crop against the disease during early stages of growth. In addition, it reduced the number of sprays and increased tomato yield.
\end{abstract}

Additional keyword: Bemisia tabaci

In Sudan, tomatoes are an important vegetable crop that account, for over $40 \%$ of the vegetable production area. Tomato yellow leaf curl virus (TYLCV) disease and its vector, the whitefly Bemisia tabaci (Gennadius), are the major production constraints in the country (26). No other geminiviruses occur in the area. TYLCV results in more than $70 \%$ yield reduction in Gezira, in central Sudan $(24,25)$, and reportedly causes losses up to $100 \%$ in tomato in tropical and subtropical regions $(9,16)$. For this reason, farmers extensively use several different insecticides to control TYLCV. This practice, however, has not maintained the pest and disease below the economic level. Few farmers have successfully used foliar insecticide applications to reduce whitefly populations and thus reduce secondary spread of TYLCV (23). The success of foliar-applied insecticides is dependent on proper timing of application $(13,15)$. In most cases, pesticides are used inefficiently by tomato growers in Sudan because prophylactic sprays are poorly timed and farmers usually use low doses of insecticides. Furthermore, they spray dur-

Corresponding author: Y. Sugimoto

E-mail: sugimoto@center.tottori-u.ac.jp

Accepted for publication 26 September 2000.

Publication no. D-2000-1115-01R

(C) 2001 The American Phytopathological Society ing the hot period of the day, and when it is windy, resulting in much of the pesticides being lost by drift. Thus, in addition to the high cost of application relative to net returns, serious environmental pollution and health hazards result from injudicious use of pesticides. This method of control needs a complementary integrated pest management (IPM) approach in order to reduce use of chemicals. Practical methods of biological control for most of the important pests and diseases in vegetables have not materialized. Multidisciplinary methods, however, were combined to control TYLCV $(2,18)$. Intercropping tomato with coriander (Coriandrum sativum) as a whitefly repellent can be an effective disease control strategy (1). Nevertheless, this practice may not be possible in all seasons and is not effective unless sown 2 weeks before tomatoes.

Table 1. Cultural practices used in tomato fields in Sudan during the 1997 and 1998 seasons

\begin{tabular}{lcc}
\hline & \multicolumn{2}{c}{ Farmer practice } \\
\cline { 2 - 3 } Components & Adopting IPM & Not adopting IPM \\
\hline Number of plants per hole & 1 & 2 to 3 \\
Irrigation frequency & 5 to 7 days & 10 days \\
Summer & 7 to 10 days & 15 days \\
Winter & Nitrogen as urea 129 & Nitrogen as urea 258 \\
Fertilizer kg/ha & Phosphorus as $\mathrm{P}_{2} \mathrm{O}_{5} 43$ & None \\
& Split at 4,8 , and 12 weeks & Divided at planting and \\
Fertilizer application & after planting & 4 weeks later \\
& Removed & Not removed \\
Weeds & Coriander & None \\
Intercropping & &
\end{tabular}

Imidacloprid (1-[(6-chloro-3-pyridinyl) methyl- $N$-nitro-2-imidazolidinimine]) has been introduced as a new class of insecticide that has both contact and long-lasting systemic activity against a wide range of insect pests $(14,17)$. Many of these insects are vectors of plant pathogens. Imidacloprid seed treatment has been effective in reducing insect feeding and providing indirect protection against disease transmission in wheat, barley, oats, rice, sorghum, corn, cotton, and other crops $(11,12,17)$. It provided effective control of Stewarts disease in young corn plants (17). From time of seedling emergence well into the growing season, the insecticide can protect cereals against Barley yellow dwarf virus (BYDV) (14). Rubinstein et al. (20) reported that imidacloprid can protect tomato plants caged with viruliferous insects against TYLCV for up to 25 days after application. Thereafter, disease was equally transmitted to imidacloprid-treated and untreated plants. Nevertheless, resistance to imidacloprid by $B$. tabaci is developing in southern Europe $(3,6)$ so that indiscriminate application of the insecticide cannot be utilized as a sole method of controlling B. tabaci. Multi-tactic approaches are needed for long-term control of this pest $(5,19)$. Our objectives focused on proper production practices, including cultural and chemical control methods to be exploited in an integrated fashion. Our goal is to implement these integrated strategies, in a participatory approach, with farmers. This study was undertaken to investigate the effects of Confidor on TYLCV incidence with the objective of reducing the number of sprays against the whitefly in tomato crops.

\section{MATERIALS AND METHODS}

Experiments were conducted at Gezira Scheme in the 1997 and 1998 growing 
seasons. In 1997, one trial during the winter was performed and in 1998, two trials were sown on 17 July and 17 October to test the efficacy of Confidor to suppress TYLCV in summer and winter tomato production, respectively. In all experiments, tomato variety Peto 86 California (Petoseed Co., Saticoy, CA) was directly sown on both sides of flat ridges $1.2 \times 10$ $\mathrm{m}$ and a within-row spacing of $0.5 \mathrm{~m}$. In summer, the trial was protected by a hedge of Cajanus cajan L., a plant often used to shelter tomato fields. Cultural practices for optimum tomato production and integrated pest management (IPM), as indicated in Table 1, were adhered to except for insecticide application.

Confidor at 47.6, 71.4, 95.2, and $119 \mathrm{~g}$ a.i./ha was sprayed on the soil immediately after sowing tomato seeds and again 6 weeks after sowing, at the same application rates. Treatments were compared with the farmer's conventional practice of spraying insecticides every 10 days, adopting and not adopting IPM as controls. In this case, control plots were sprayed with cypermethrins immediately after emergence of tomato seedlings and then every 10 to 12 days. Spraying with all insecticides was stopped at $50 \%$ fruit set.

The experimental design was a random block with three replicates. All treatments were randomly arranged in subplots of 18 flat ridges each. Double guard rows were established between subplots and around the perimeters of the experiments. In addition, shelters were used during spraying to reduce drift. Both Confidor-treated and control plots received two sprays with Danitol 20 against leaf miner (Liriomyza sp.) in both seasons.

Effects of Confidor on disease incidence were regularly monitored by counting the number of symptomatic plants in the middle eight rows of each subplot. Yield data of each replicate were also recorded. Symptom percentage data were transformed to arcsine, analyzed by analysis of variance, and then back transformed.

\section{RESULTS}

Confidor treatments usually resulted in a lower disease incidence than standard application of cypermethrins whether adopting IPM practices or not. Treatments with 95.2 and $119 \mathrm{~g}$ a.i./ha gave the highest disease reduction. In winter 1997 and 1998, there was no TYLCV in plots treated with these rates of Confidor up to 6 weeks after sowing. Low infection (0.6 and 2.7\%) was observed in the control plots adopting IPM and in plots treated with lower rates of Confidor. The first record of symptoms in the higher-rate Confidor-treated plots was observed 8 weeks after sowing where disease incidence was 2.0 to $4.0 \%$ (Fig. 1A). Infection level in the control plots adopting IPM, albeit regularly sprayed, was significantly $(P<0.01)$ higher than in Confidor-treated plots. On the other hand, disease incidence in the control plots not adopting IPM sharply increased from $13 \%$ at 8 weeks after sowing to $43 \% 4$ weeks later. Use of Confidor at all rates resulted in low disease incidence throughout the season. By the end of the season, however, the higher rates of Confidor were superior to the lower rate, indicating that they had prolonged activity. In summer 1998, although the population of whiteflies was constantly lower than in the winter plots (data not shown), a comparable incidence of TYLCV was observed late in the season in all Confidor treatments (Fig. 1B and C). The control IPM-treated plots had 2.9, 8.2, 14.3 , and $19.7 \%$ symptomatic plants compared with $3.1,7.5,13.7$, and $17.4 \%$ at 6 , 8,10 , and 12 weeks after sowing, respectively. Late in the season, the lower rate of Confidor treatment resulted in higher disease incidence (11 to $17 \%$ ) in winter compared with summer. Disease incidence in the three higher rates of Confidor applications, however, remained significantly $(P<$ $0.01)$ lower than both control treatments throughout the season. No disease was
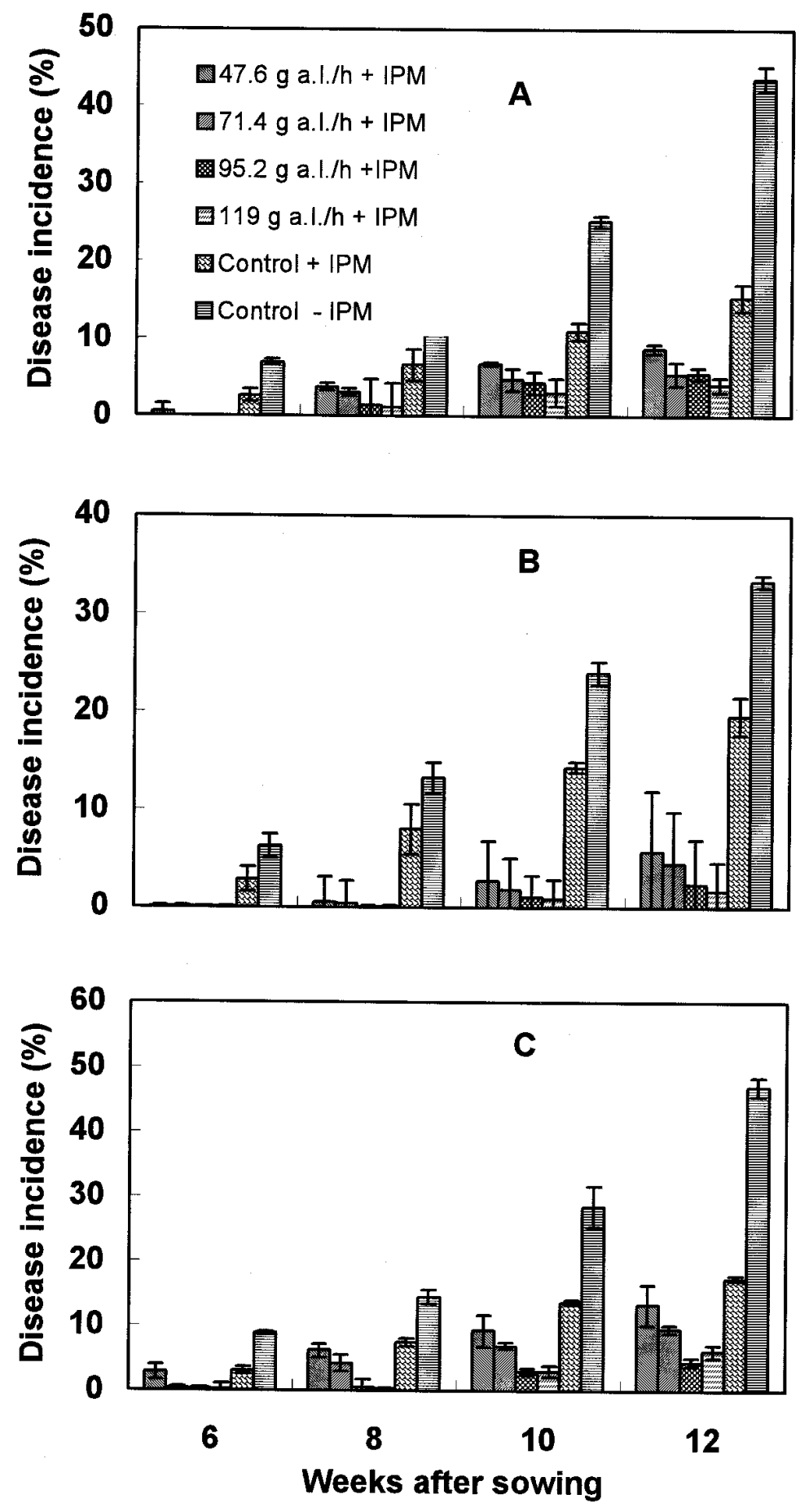

Fig. 1. Incidence of Tomato yellow leaf curl virus based on symptoms in tomato trials treated with different rates of imidacloprid. A, Winter 1997; B, Summer 1998; C, Winter 1998. 
observed up to 8 weeks after application of Confidor at 95.2 and $119 \mathrm{~g}$ a.i./ha in the summer 1998 trial, and only minor disease (1.1 to $1.3 \%$ ) was observed 12 weeks after sowing in winter. Farmer plots not adopting IPM and regularly sprayed with insecticides, however, were severely infected by TYLCV in both seasons (Fig. 1B and C). The highest disease incidence in plots adopting IPM was consistently noted in plots not receiving Confidor in all dates and seasons. These levels, however, were substantially lower than that in the plots not adopting IPM. Disease levels in Confidor-treated plots remained stable throughout the season, increasing 6 weeks after sowing to reach the maximum levels after another 6 weeks. In fields where IPM was not adopted, the disease increased more rapidly from 6 to $33 \%$ and from 9 to $47 \%$ between 6 and 12 weeks in summer and winter, respectively.

In winter 1997, plots treated with the three highest rates of Confidor had similar yields and were higher than other treatments. The lowest rate of Confidor resulted in yields comparable to the IPM control (Fig. 2). Similar results were obtained in summer and winter seasons 1998. However, the yields of all treatments in winter 1998, despite a higher disease incidence, were significantly $(P<0.01)$ higher compared with the yields in summer 1998 and winter 1997. In comparison with the highest rate of Confidor, in the IPM control plots, with standard insecticides, the disease reduced the yield, by 9,22 , and $10 \%$ in winter 1997, and summer and winter 1998, respectively. The disease reduced the yield in the control plots, spraying standard insecticides but not adopting IPM, relative to those adopting IPM by 40,41 , and $44 \%$ in winter 1997 , and winter and summer 1998, respectively.
The regression analysis indicated that there was a strong correlation between disease incidence and yield in winter 1997, and summer and winter $1998\left(R^{2}=0.983\right.$, 0.947 , and 0.990 , respectively).

\section{DISCUSSION}

Application of Confidor insecticide at sowing appears to be an effective method to reduce the level of TYLCV incidence in tomatoes. In view of whitefly mobility and rate of development (6), protection of crops against vector population build up during the early stages of growth reduces secondary spread of the virus from infected loci. Our data indicate that Confidortreated plants could be attacked by viruliferous whiteflies that succeeded in transmitting the disease before they died. The ability of the insects to inoculate Confidortreated plants depends on the rates of the chemical applied and time after application. Similar findings were reported on the effect of Confidor on whitefly and other insect-transmitted viruses $(3,11,12,14,20)$. Whiteflies were reported to transmit TYLCV to imidacloprid-treated tomato plants (20). Nevertheless, imidacloprid greatly reduced whitefly populations and incidence of geminiviruses (18). In Florida it was one of the successful tactics to control Tomato mottle virus when applied at planting time (18). In the Dominican Republic, several applications of imidacloprid starting at transplant production were used to control TYLCV (18).

The activity of Confidor decreased over time so that supplementary sprays were needed 6 weeks after sowing. This compound, however, reduced the number of standard sprays needed by farmers in $\mathrm{Su}$ dan. Applications of cypermethrins did not offer plants the same protection against the disease as Confidor treatments. Early inci-

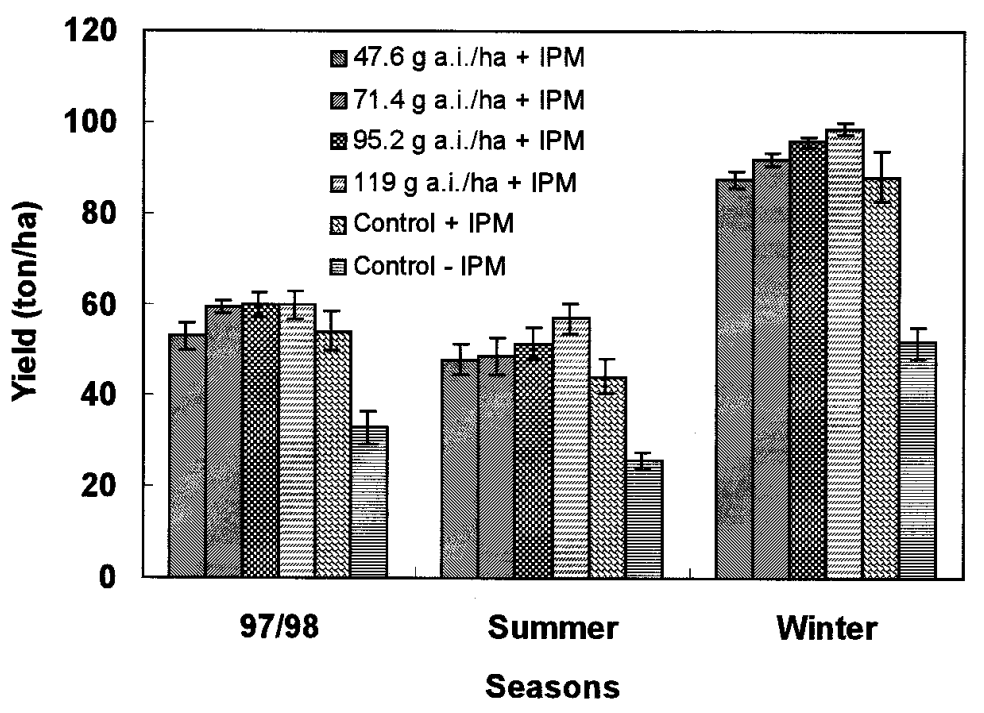

Fig. 2. Yields of tomato crops treated with different rates of imidacloprid in comparison with standard insecticides in combination with integrated pest management (IPM) and in absence of IPM during the 1997 and 1998 seasons. dence of the disease in our control plots was probably due to the time lapse between emergence of seedlings and insecticidal applications or to the short activity of the insecticides used. Spread of the disease, however, was controlled by regular spraying in the control plots adopting IPM but not in those without IPM, despite the 16 sprays used. In this case, IPM helped the growth of the crop to keep ahead of the disease. On the other hand, high crop density, excessive use of fertilizers, irregular irrigation, lack of weed control, resulted in poor tomato growth and plants that were more vulnerable to disease (2). One of the most pronounced effects of TYLCV in the tomato plants was severe stunting $(4,10)$ which was observed only in plots not adopting IPM. Intercropping tomato with coriander, a crop repellant to whiteflies, contributed to indirect control of TYLCV in the IPM plots (1). Disease incidence was lower than expected in the summer crop, when tomato plants exhibit more severe symptoms and when a single viruliferous whitefly can efficiently spread the virus (25). In this trial, all treatments had similar disease incidence between summer and winter crops by the end of the season. Rubinstein et al. (20) found that viruliferous insects could inoculate TYLCV to imidacloprid-treated and caged tomato plants before they died. In our trials, imidacloprid protected tomato plants under natural conditions for 6 to 8 weeks after sowing. This protection when used in a multi-component package resulted in good plant vigor and consequently in higher yields.

The higher level of disease during winter was probably due to the presence of a highly infected tomato crop in adjacent fields and prevalence of many alternative virus reservoirs among the cultivated crops and weed flora (21). During the summer, the dry season in Sudan, alternative hosts are not available and the whitefly population is generally low. However, tomatoes are grown throughout the year and all cultivated varieties are susceptible to TYLCV. Whitefly host-free periods reduce insect populations and may also decrease the number of viruliferous vectors. In Israel, a 1-month crop-free period was enforced in 1986, and since then no economic damage caused by insect-borne virus has been recorded (22). In Sudan, cultivation of summer tomato is limited due to environmental conditions and risks encountered by TYLCV. Nevertheless, summer tomatoes bring high net returns that compensate for low yields.

There was a clear correlation between disease incidence and yield. Low TYLCV incidence in Confidor-treated plots was reflected in higher yields. The low yield in summer tomato compared with winter, despite similar disease incidence, was probably due to environmental conditions. High yields from IPM control plots com- 
pared with those not adopting and which received more applications of insecticides, indicate that yield increase was not due only to the use of Confidor. Rather, it resulted from the collective effects of good husbandry practices on plant vigor and health. Effective management strategies should involve cultural practices such as plant population, fertilization and irrigation management, and elimination of wild host plants of the virsus which do occur in and around the tomato crop to reduce spread of the virus.

In many tomato-producing areas in Gezira, secondary spread of TYLCV appears to be the greatest contributor to disease epidemics. Confidor may substantially reduce the disease in this region and is less damaging to the environment than most conventional insecticides $(7,8)$. A shorter period between the first and second applications of Confidor or use of higher rates might result in sufficient protection against the disease.

\section{ACKNOWLEDGMENTS}

This study was partially funded by Bayer Company, Germany. The authors thank J. B. Jones, University of Florida, for the criticism and valuable suggestions he made on the manuscript.

\section{LITERATURE CITED}

1. Ahmed, N. E., Mohamed, M. B., and Abdelrahman, A. A. 1996. Effects of Coriandrum sativum as a repellent to whitefly on tomato yellow leaf curl virus and yield in farmers fields. Final report. PP-12 in: Integrated Pest Management FAO/ARC (GCP/SUD/025/ NET).

2. Ahmed, N. E., and Wani, P. 1998. Integrated control of some vegetable diseases in relation to improvement of yield. Pages 30-51 in: Third Annual Review and Planning Meeting of the FAO/ARC IPM Project on Development and Application of Integrated Pest Management in Vegetables, Wheat, and Cotton (Phase IV); GCP/SUD/025/NET. Z. T. Dabrowski, ed. ICIPE Science Press, Nairobi, Kenya.

3. Cahill, M., Gorman, K., Day, S., Denholm, L.,
Elbert, I., and Nauen, R. 1996. Baseline determination of resistance to imidacloprid in Bemisia tabaci (Homoptera: Aleyrodidae). Bull. Ent. Res. 86:343-349.

4. Cohen, S., and Antignus, Y. 1994. Tomato yellow leaf curl virus, a whitefly-borne geminivirus of tomatoes. Adv. Dis. Vector Res. 10:259-288.

5. Dabrowski, Z. T., Alsaffar, A., and Abderahman, A. A. 1994. Integrated Pest Management on Vegetable Crops in Sudan: Development and Implementation Strategy. Pages 24-32 in: Integrated Vegetable Crop Management FAO/Government of the Sudan Cooperative Project, GCD/ SUD/02A/NET. Z. T. Dabrowski, ed. ICIPE Science Press, Nairobi, Kenya.

6. Devine, J. G., Ishaaya, I., Horowitz, A. R., and Denholm, I. 1998. Effects of piperonyl butoxide on Bemisia tabaci Genn. (Homoptera:Aleyrodidae): mortality, development, parasitism, and predation in Israeli cotton fields. Crop Prot. 17:717- 726.

7. Elbert, A., Becker, B., Hartwig, J., and Erdelen, C. 1991. Imidacloprid, a new systemic insecticide. Pflanzenschutz-Nachr. Bayer 44:113-136.

8. Fluckiger, C. R., Kristinsson, H., Senn, R., Rindlisbacher, A., Bucholzer, H., Voss, G. 1992. CGA-215944, a novel agent to control aphids and whiteflies. Pages $21-28$ in: Proceedings Brighton Crop Protection Conference.

9. Friedmann, M., Lapidot, M., Cohen, S., Pilowsky, M. 1998. Novel source of resistance to tomato yellow leaf curl virus exhibiting a symptomless reaction to viral infection. J. Am. Soc. Hortic. Sci. 123:1004-1007.

10. Geneif, A. A. 1984. Breeding for resistance to tomato yellow leaf curl virus in tomatoes in Sudan. Acta. Hortic. 143:469-484.

11. Gourmet, C., Hewings, A. D., Kolb, F. L., and Smyth, C. A. 1994. Effect of imidacloprid on nonflight movement of Ropalosiphum padi and the subsequent spread of barley yellow dwarf virus. Plant Dis. 78:1098-1101.

12. Gourmet, C., Kolb, F. L., Smyth, C. A., and Pedersen, W. L. 1996. Use of imidacloprid as a seed treatment insecticide to control barley yellow dwarf virus in oat and wheat. Plant Dis. 80:136-141.

13. Gray, S. M., and Bergstrom, G. C. 1992. Imidacloprid controls cereal aphids and alters barley yellow dwarf epidemiology. (Abstr.) Phytopathology 82:1073.
14. Gray, S. M., Bergstrom, G. C., Vaughan, R., Smith, D. M., and Kalb, D. W. 1996. Insecticidal control of cereal aphids and its impact on the epidemiology of the barley yellow dwarf luteoviruses. Crop Prot. 15:687-697.

15. Kendall, D. A., Smith, B. D., Burchill, L. G., Chinn, N. E., and Lyons, C. H. 1985. Comparison of insecticide application dates for the control of barley yellow dwarf virus in winter barley cultivar Igri and winter wheat cultivar Rapier. Ann. Appl. Biol. 102 (Suppl.):10-11.

16. Lapidot, M., Friedmann, M., Lachman, O. and Yehezkel, A. 1997. Comparison of resistance level to tomato yellow leaf curl virus among commercial cultivars and breeding lines. Plant Dis. 81:1425-1428.

17. Munkvold, G. P., McGee, D. C., and Iles, A 1996. Effects of imidacloprid seed treatment of corn on foliar feeding and Erwinia stewartii transmission by the corn flea beetle. Plant Dis. 80:774-749.

18. Polston, J. E., and Anderson, P. K. 1997. The emergence of whitefly-transmitted geminiviruses in tomato in the Western Hemisphere. Plant Dis. 81:1358-1369.

19. Risch, S. J., Andow, D., and Altieri, M. A. 1983. Agroecosystems diversity and pest control. Environ. Entomol. 12: 625-629.

20. Rubinstein, G., Morin, S., Czosnek, H. 1999. Transmission of tomato yellow leaf curl geminivirus to imidacloprid treated tomato plants by the whitefly Bemisia tabaci (Homoptera; Aleyrodidae). J. Econ. Entomol. 92:658-662.

21. Tarr, S. A. J. 1955. The fungi and plant diseases of Sudan. Commonwealth Mycological Institute, Kew, U.K.

22. Ucko, O., Cohen, S., Ben Joseph, R. 1998. Prevention of virus epidemics by a crop- free period in the Arava region of Israel. Phytoparasitica 26:313-321.

23. Yassin, A. M. 1975. Epidemics and chemical control of leaf curl virus disease of tomato in Sudan. Exp. Agric. 11:161-165.

24. Yassin, A. M. 1984. Leaf curl epidemic in tomato and possible control strategies. Acta Hortic. 143: 457-468.

25. Yassin, A. M., Abusalih, H. S., and Dafalla, G. A. 1982. Leaf Curl epidemic, a threat to tomato production in Sudan. Ann. Virol. 133:175-181.

26. Yassin, A. M., and Nour, M. A. 1965 . Tomato leaf curl diseases in Sudan and their relation to tobacco leaf curl. Ann. Appl. Biol. 56:207217. 